\title{
Molecular Detection of Rickettsia spp. and Coxiella burnetii in Cattle, Water Buffalo, and Rhipicephalus (Boophilus) microplus Ticks in Luzon Island of the Philippines
}

\author{
Remil L. Galay ${ }^{1, *}$, Melbourne R. Talactac ${ }^{2}$, Bea V. Ambita-Salem ${ }^{1}$, Dawn Maureen M. Chu ${ }^{1}$, \\ Lali Marie O. dela Costa ${ }^{1}$, Cinnamon Mae A. Salangsang ${ }^{1}$, Darwin Kyle B. Caracas ${ }^{1}$, \\ Florante H. Generoso ${ }^{2}$, Jonathan A. Babelonia ${ }^{2}$, Joeneil L. Vergano ${ }^{2}$, Lena C. Berana ${ }^{2}$, \\ Kristina Andrea C. Sandalo ${ }^{1}$, Billy P. Divina ${ }^{1}$, Cherry R. Alvarez ${ }^{2}$, Emmanuel R. Mago ${ }^{2}$, \\ Masako Andoh ${ }^{3}$ and Tetsuya Tanaka ${ }^{4, *}$ \\ 1 Department of Veterinary Paraclinical Sciences, College of Veterinary Medicine, University of the Philippines \\ Los Baños, College, Laguna 4031, Philippines; Beaambita@gmail.com (B.V.A.-S.); \\ dmchu@up.edu.ph (D.M.M.C.); lodelacosta@up.edu.ph (L.M.O.d.C.); casalangsang@up.edu.ph (C.M.A.S.); \\ dbcaracas@up.edu.ph (D.K.B.C.); kacsandalo@gmail.com (K.A.C.S.); bpdivina@up.edu.ph (B.P.D.) \\ 2 Department of Clinical and Population Health, College of Veterinary Medicine and Biomedical Sciences, \\ Cavite State University, Indang, Cavite 4122, Philippines; melbourne.talactac@gmail.com (M.R.T.); \\ florantegeneroso@gmail.com (F.H.G.); jonathanbabelonia@gmail.com (J.A.B.); \\ joeneilbergs@gmail.com (J.L.V.); lenaberana777@gmail.com (L.C.B.); cherryreyesalvarez@gmail.com (C.R.A.); \\ emman.mago.7081@gmail.com (E.R.M.) \\ 3 Laboratory of Public Health, Joint Faculty of Veterinary Medicine, Kagoshima University, Korimoto 1-21-24, \\ Kagoshima 890-0065, Japan; masako@vet.kagoshima-u.ac.jp \\ 4 Laboratory of Infectious Diseases, Joint Faculty of Veterinary Medicine, Kagoshima University, Korimoto \\ 1-21-24, Kagoshima 890-0065, Japan \\ * Correspondence: rlgalay@up.edu.ph (R.L.G.); k6199431@kadai.jp (T.T.); Tel.: +63-049-536-2728 (R.L.G.); \\ +81-99-285-3570 (T.T.)
}

Received: 10 March 2020; Accepted: 2 April 2020; Published: 4 April 2020

\begin{abstract}
Rickettsia and Coxiella burnetii are zoonotic, tick-borne pathogens that can cause febrile illnesses with or without other symptoms in humans, but may cause subclinical infections in animals. There are only a few reports on the occurrence of these pathogens in cattle and water buffalo in Southeast Asia, including the Philippines. In this study, molecular detection of Rickettsia and C. burnetii in the blood and in the Rhipicephalus (Boophilus) microplus ticks of cattle and water buffalo from five provinces in Luzon Island of the Philippines was done. A total of 620 blood samples of cattle and water buffalo and 206 tick samples were collected and subjected to DNA extraction. After successful amplification of control genes, nested PCR was performed to detect gltA of Rickettsia and com 1 of C. burnetii. No samples were positive for Rickettsia, while 10 (cattle $=7$, water buffaloes $=3$ ), or $1.6 \%$ of blood, and five, or $1.8 \%$ of tick samples, were C. burnetii-positive. Sequence analysis of the positive amplicons showed $99-100 \%$ similarity to reported C. burnetii isolates. This molecular evidence on the occurrence of C. burnetii in Philippine ruminants and cattle ticks and its zoonotic nature should prompt further investigation and surveillance to facilitate its effective control.
\end{abstract}

Keywords: Coxiella burnetii; Rickettsia; Q fever; rickettsiosis; tick-borne pathogens 


\section{Introduction}

In the Philippines, cattle and water buffalo are of economic importance, contributing significantly to the agricultural sector. They are mainly utilized in the production of meat, milk, and additionally for water buffalo, for draft power [1]. The total population of cattle and water buffalo (locally known as carabao in the Philippines) as of January 2020 is $2.54 \mathrm{M}$ and $2.87 \mathrm{M}$, respectively [2,3]. Through efforts of the Philippine government, there has been a steady increase in large ruminant production in recent years. Diseases that can affect the health and production of these animals, including those that are zoonotic, have an impact on the lives of animal raisers and product consumers. Tick-borne pathogens (TBPs) affect the ruminant population worldwide and are widely distributed, particularly in the tropics and subtropics, representing an essential proportion of all animal diseases that constrain the livelihood of farmers. Among these TBPs of ruminants, Rickettsia and Coxiella burnetii can pose great threats to public health. However, little is known about the occurrence of these TBPs in Southeast Asia, including the Philippines.

Rickettsia and C. burnetii are obligate, intracellular, Gram-negative bacteria that can cause febrile illnesses of varying severity in humans. Aside from being transmitted by ticks, Rickettsia can also be transmitted by fleas, lice, and mites [4], whereas C. burnetii is usually acquired by humans through the inhalation of contaminated aerosol and ingestion of contaminated milk from infected animals [5]. Rickettsioses are known to occur worldwide, and have historically shown different patterns of emergence, from seasonal outbreaks to large-scale epidemics [6]. They are endemic in North and South America, Europe, Africa, and Asia [7]. Meanwhile, C. burnetii has been detected almost all over the world, except New Zealand [8,9]. Both pathogens can infect a wide range of hosts, including wild and domestic animals, as well as humans. Serological [10-15] and molecular studies [16-22] have demonstrated the occurrence of these pathogens in ruminants and associated ticks, implying their role as a potential source of infection for livestock workers.

Rickettsia is mainly classified into the spotted fever group (SFG) and the typhus group (TG), based on serological characteristics, with the former further divided into the ancestral group (AG) and the transitional group (TRG) [23]. The clinical presentation of rickettsioses in animals vary from subclinical to severe. In cattle and goats, although seroconversion was observed upon inoculation; clinical signs, however, were not observed [24]. In contrast, infections with Rickettsia are considered the second highest cause of non-malarial febrile illness in humans worldwide, and are associated with high morbidity and rising mortality rates [25].

Infection with C. burnetii in animals is commonly asymptomatic, but can also lead to abortion and stillbirths in pregnant mammals [5]. It can also induce pneumonia and the delivery of weak calves. The female uterus and mammary glands are the primary sites of chronic C. burnetii infection [26]. In cattle, metritis is frequently the only manifestation of the disease [27]. Domestic ruminants represent the most frequent source of human infection, of which cattle, goats, and sheep are considered as the primary reservoirs $[26,28]$. In humans, C. burnetii infection, known as $\mathrm{Q}$ fever, may be acute or chronic [5]. The acute stage may be asymptomatic, or it is exhibited by non-specific clinical signs, such as fever, headache, nausea, vomiting, and myalgia. The chronic stage is characterized by more severe pathology, such as endocarditis, hepatitis, vasculitis, and chronic fever states [29].

The cattle tick Rhipicephalus (Boophilus) microplus is widely spread in the Philippines. Several studies have been done on TBPs affecting cattle [30]. However, few studies have been done to determine the occurrence of Rickettsia and C. burnetii. Camer et al. [31] demonstrated the presence of antibodies against the SFG and TG Rickettsia and C. burnetii in humans by indirect immunofluorescent antibody test (IFAT), whereas Cardona [32] used complement fixation for serological testing of C. burnetii in domestic ruminants and humans. Recently, a study from our group utilizing nested PCR provided evidence for the presence of Rickettsia in dogs in the Philippines [33]. Here, we investigate the presence of Rickettsia and C. burnetii in cattle and water buffalo, as well as R. (B.) microplus ticks, in selected provinces in Luzon, Philippines, through nested PCR. Knowledge of the presence of these pathogens 
is crucial in ascertaining the potential risk for people working closely with those animals, and in implementing appropriate control measures.

\section{Materials and Methods}

\subsection{Study Area and Collection of Samples}

Blood of cattle and water buffalo, as well as ticks, were collected in five provinces in Luzon, Philippines-namely, Cavite, Laguna, Batangas, Rizal, and Quezon, collectively known as CALABARZON or Region IV-A (Figure 1). This region, located at $14.1008^{\circ} \mathrm{N}, 121.0794^{\circ} \mathrm{E}$, is among the regions of the Philippines with a high population of large ruminants, having 269,677 cattle [2] and 177,661 water buffaloes [3]. The collection of samples was done between March 2016 and October 2019, from a total of 620 animals (512 cattle and 108 water buffaloes), regardless of breed type, age and sex, and health status, from selected commercial and backyard raisers who agreed to participate in this study. Information on the animals, including health status, was noted. Blood was collected from each animal using a $5 \mathrm{~mL}$ syringe with an $18 \mathrm{G}$ needle, and was transferred to a tube containing ethylenediaminetetraacetic acid (EDTA). Aside from blood, ticks were also collected from those animals, if present, using a specialized tick removal tool (O'tom / Tick Twister, H3D, Lavancia, France) and were placed in glass vials. All ticks were morphologically identified as $R$. (B.) microplus in the laboratory under a stereomicroscope, based on the description of Barker and Walker [34], and were sorted according to developmental stage and sex. Nymphs and male adults collected from the same animal were pooled separately and then processed accordingly, while partially-fed and engorged female ticks were processed individually. The collection procedures in the animals have been approved by the Institutional Animal Care and Use Committee (IACUC) of the College of Veterinary Medicine, University of the Philippines Los Baños, and of Cavite State University, following applicable national guidelines.

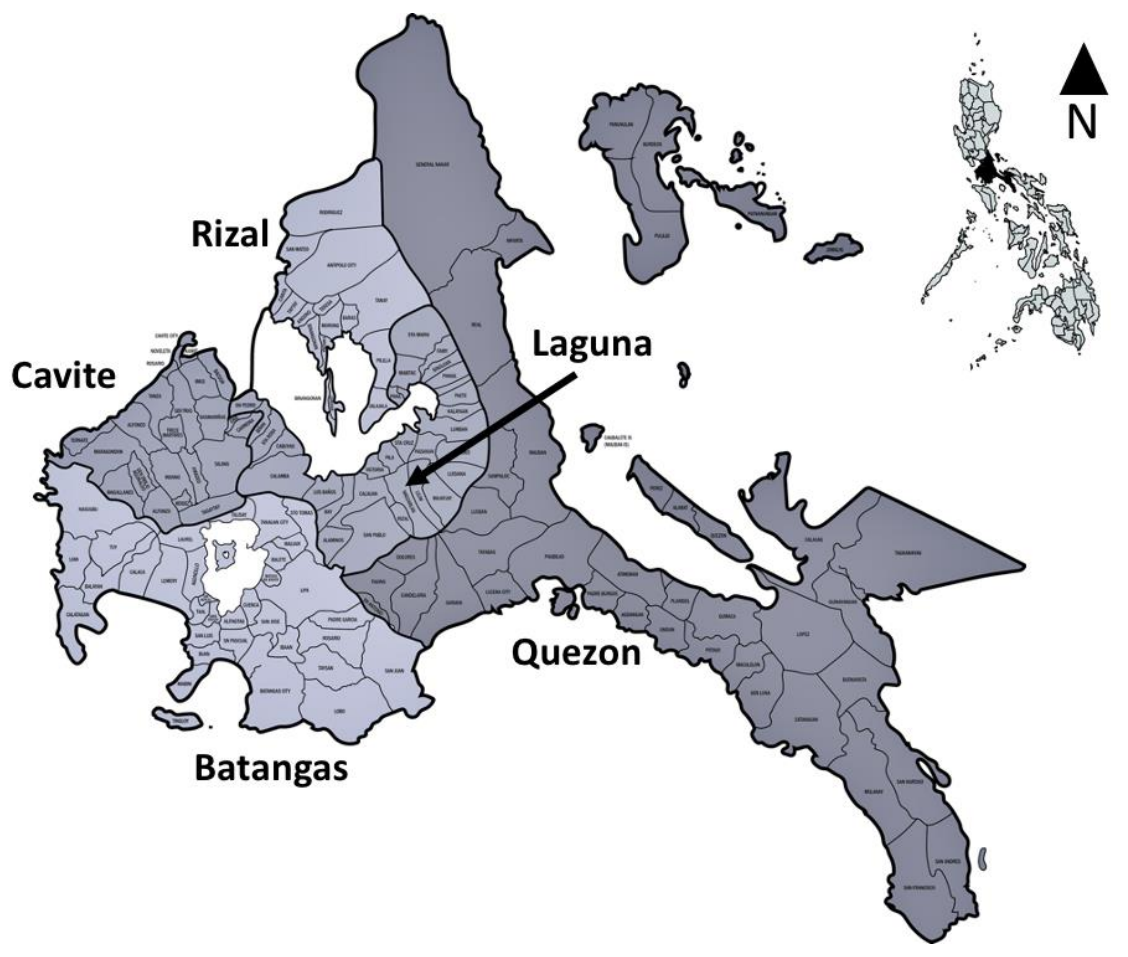

Figure 1. Map of the study area, Region IV-A or CALABARZON, comprised of five provinces (Cavite, Laguna, Batangas, Rizal, and Quezon). The smaller map was created using the online software MapChart (https://mapchart.net/). 


\subsection{Extraction of DNA from Blood and Tick Samples}

Commercial extraction kits (innuPREP DNA/RNA Mini Kit and blackPREP Tick DNA/RNA Kit, Analytik Jena, Jena Germany) were used to extract DNA from blood and tick samples following the manufacturer's protocol, with some modifications. Specifically, the modifications included tick homogenization in lysis buffer, with the aid of a digital cell disruptor (Disruptor Genie ${ }^{\circledR}$, Scientific Industries Inc., New York, United States), and were incubated at room temperature for at least $30 \mathrm{~min}$ to allow complete lysis. All DNA samples were stored at $-40^{\circ} \mathrm{C}$ until used for PCR assays.

\subsection{PCR Detection of Control Genes and Pathogens}

To confirm the success of DNA extraction before pathogen detection, conventional PCRs for the amplification of actin and mt-rrs genes in the blood and tick DNA samples, respectively, were performed, as described previously $[35,36]$. After the successful amplification of control genes, nested PCRs targeting the citrate synthase ( $g l t A)$ gene of Rickettsia [37] and the com 1 gene, which encodes a 27-kDa outer membrane protein of C. burnetii [38], were performed. PCR mixtures consisted of $2 x$ PCR buffer, 10 pmol each of forward and reverse primers, polymerase (Tks Gflex DNA Polymerase, TaKaRa, Shiga, Japan), nuclease-free water, and a template (1 $\mu \mathrm{L}$ DNA or first PCR product for $10 \mu \mathrm{L}$ mixtures). All primers used in this study are listed in Table S1 in supplementary materials, while the PCR conditions are shown in Table S2 in supplementary materials. Negative controls containing nuclease-free water and positive controls containing $R$. japonica and C. burnetii DNA were included. Electrophoresis of PCR products was done in $2 \%$ agarose gel in 1x Tris-acetate-EDTA (TAE) buffer, and bands were visualized through a gel documentation system (Bio-Print, Vilber, Lourmat, France) after being stained with ethidium bromide in $1 x$ TAE.

\subsection{Sequence and Data Analysis}

Upon visualization of positive bands, amplicons were excised and purified using a commercial kit (NucleoSpin Gel and PCR Clean-up kit, Macherey-Nagel, Leicestershire, England) following the recommended protocol. The purified amplicons were sent to a third-party laboratory for capillary sequencing, using the forward primer for nested PCR. The similarity of obtained amplicon sequences was determined by multiple nucleotide sequence alignment using an online software MAFFT version 7 (https://mafft.cbrc.jp/alignment/server/index.html). The nucleotide sequence readings obtained were compared to previously reported sequences using the Basic Local Alignment Search Tool, or BLAST (https://blast.ncbi.nlm.nih.gov/Blast.cgi). A phylogenetic tree was constructed using online software (http://www.phylogeny.fr). The detection rate of the pathogen was determined by dividing the number of positive samples by the number of samples per source (e.g. cattle, water buffalo, and ticks) and is expressed as a percentage.

\section{Results}

Table 1 shows the breakdown of blood and tick samples collected from the five provinces in Luzon, Philippines, and the corresponding results of the nested PCR assays. The 620 animals were comprised of 108 males and 512 females. With regard to their purpose, 271 animals are being raised for milk (dairy type), 285 for meat (beef type), and 64 as draft animals. Only 165 animals were found to have ticks at the time of sample collection. A total of 206 tick samples, comprised of 14 pools of nymphs, 31 pools of male ticks, and 161 individual female ticks, was tested. 
Table 1. Number and percent (\%) of blood samples from cattle, water buffalo, and ticks collected from selected provinces in Luzon, Philippines, that tested positive for Coxiella burnetii, based on nested PCR. All the samples were negative for Rickettsia. $n=$ number of examined samples.

\begin{tabular}{ccccccc}
\hline & \multicolumn{2}{c}{ Cattle } & Water Buffalo & \multicolumn{2}{c}{ Ticks * } \\
\hline Province & $n$ & $\begin{array}{c}\text { No. (\%) of } \\
\text { C.burnetii-positive }\end{array}$ & $n$ & $\begin{array}{c}\text { No. (\%) of } \\
\text { C. burnetii- positive }\end{array}$ & $n$ & $\begin{array}{c}\text { No. (\%) of } \\
\text { C. burnetii- positive }\end{array}$ \\
\hline Cavite & 100 & 0 & 0 & - & 89 & 0 \\
Laguna & 111 & 0 & 11 & 0 & 18 & 0 \\
Batangas & 120 & 0 & 8 & 0 & 50 & 0 \\
Rizal & 87 & $2(2.3)$ & 0 & - & 0 & - \\
Quezon & 94 & $5(5.3)$ & 89 & $3(3.4)$ & 49 & $5(10.2)$ \\
Total & 512 & $7(1.4)$ & 108 & $3(2.8)$ & 206 & $5(2.4)$ \\
\hline
\end{tabular}

* as pooled samples.

DNA was successfully extracted from each sample, as shown by positive amplification of the control genes actin and $m t$-rrs. In the nested PCR assay, bands of $381 \mathrm{bp}$ and $438 \mathrm{bp}$ were considered positive for Rickettsia and C. burnetti, respectively, as observed in respective positive controls. All blood and tick samples from both animal hosts were negative for Rickettsia. In contrast, there were 10 blood samples positive for C. burnetii, of which seven (1.4\%) were from cattle and three $(2.8 \%)$ were from water buffalo (Table 1). The positive animals were all female, and came from seven different municipalities in two provinces (Rizal and Quezon). Additionally, six of those animals are being raised for dairy, three for meat, and one as a draft animal. Furthermore, five (2.3\%) tick samples were also positive for C. burnetii. Three of those tick samples were females, and two were pooled male tick samples, which were all collected from Quezon province.

All C. burnetii positive amplicons were subjected to nucleotide sequencing. The alignment of obtained nucleotide sequences revealed that all the amplicons are 100\% similar. Furthermore, BLAST analysis revealed that the amplicons share $100 \%$ identity with reported C. burnetii isolates, such as the RSA439, CPBBU1, and Fars-GH4 strains, having 99\% query coverage. Construction of a phylogenetic tree was attempted. However, the isolates from this study and those isolated in other countries were grouped together, with no observed ramifications (data not shown). The sequence of one amplicon was deposited in the DNA Data Bank of Japan (accession number: LC534651).

\section{Discussion}

The present study was conducted to determine the presence of two zoonotic, tick-borne pathogens, Rickettsia and C. burnetii, in cattle, water buffalo, and ticks in the Philippines. None of the samples tested positive for Rickettsia, suggesting the absence of the pathogen in the areas where the samples were collected. Prior to this study, there were no reports of the occurrence of Rickettsia in these animal hosts in the Philippines. Previous studies in the country only reported the detection of antibodies against SFG Rickettsia in dogs and rats [39], as well as antibodies against SFG and TG Rickettsia in humans [31]. Recently, our group detected Rickettsia in dogs from Laguna, one of the provinces in this study, through the same nested PCR employed in this study. It was found that the amplicons were highly identical to $R$. japonica after sequence analysis [33].

Evidence of rickettsiosis in ruminants have been reported in other countries. Serological studies using ELISA and IFAT have been mostly successful in demonstrating the presence of antibodies against Rickettsia in ruminants, including cattle [15,40-42]. On the other hand, previous studies on PCR detection in the blood reported negative results $[40,41]$, which is due to the low titer or absence of rickettsemia [41,43]. The same reason may explain the negative results obtained in this study. A study on the detection of vector-borne pathogens, including Rickettsia in ungulates in Hungary, was conducted using real-time PCR targeting $23 S$ rRNA and gltA for R. helvetica and other Rickettsia, respectively [44]. Whereas none of the blood samples from the water buffaloes tested positive for 
$R$. helvetica or other rickettsiae, $R$. helvetica was detected in a blood sample and a spleen sample from a deer. Moreover, a deer spleen sample also tested positive for an unknown Rickettsia [44]. A recent study in Cameroon showed the successful detection of Rickettsia in cattle using conventional PCR targeting the $16 \mathrm{~s} r D N A$ gene, with a prevalence of $14.3 \%$ [45].

Nevertheless, aside from the possible reasons for the negative results discussed above, the limitations of the detection method employed in this study must also be considered. Whereas nested PCR is known for high sensitivity, it may be unable to detect Rickettsia if the bacterial load in the blood is less than $100 / \mathrm{mL}$, and if the DNA yield after extraction is poor [46]. The gene targeted for Rickettsia detection in this study is gltA, which is considered a highly conserved gene and is very useful for phylogenetic analysis [47]. However, for detection, it is most useful for SFG and TG rickettsiae. For future studies, a real-time PCR targeting a $74 \mathrm{bp}$ fragment of glt $A$ should be performed due to its high sensitivity, as it is capable of detecting one copy number per reaction [48]. Moreover, sequential assays targeting other genes, such as $о т p A$ and $о т p B$, in addition to glt $A$, may be performed to ensure higher sensitivity [49].

Concerning the negative results of Rickettsia nested PCR in ticks in the current study, they are in contrast to the report of previous studies that were able to detect Rickettsia in various ticks from domestic ruminants, with Rickettsia being the most detected tick-borne pathogen [50-53]. In those studies, the gltA gene was amplified through real-time PCR or nested PCR. A study in Thailand utilizing conventional PCR targeting gltA also reported the detection of Rickettsia in R. (B.) microplus ticks [21]. Aside from pathogenic species, endosymbiont Rickettsia has also been identified and characterized in Ixodes ticks [54,55]. Future studies should also employ other methods and target different genes for the detection of Rickettsia in ticks, as mentioned above.

The current findings on the occurrence of $C$. burnetii in large ruminants and cattle ticks support a previous report on the detection of antibodies against $C$. burnetii in cattle and water buffalo in the country, using a complement fixation test [32]. The origin of the seropositive animals in that study was different from the origin of the nested PCR positive animals in our study, which together provide evidence that $C$. burnetii is present in several provinces of the Philippines. BLAST analysis revealed a very high identity shared with reported isolates of C. burnetii from other countries. Due to the highly conserved nature of the targeted com 1 gene [38], we were unable to come up with a good phylogenetic analysis. Hence, it is recommended that another gene, such as $16 s \mathrm{~s} R N A$, be amplified to further validate the amplicons and to elucidate the relationship of $C$. burnetti isolates from the Philippines with those from other countries.

The C. burnetii-positive animals in this study were not observed with any clinical signs at the time of blood collection, except for two that were noted to have poor body condition score, suggesting possible subclinical infection. This observation corroborates a previous report that seropositive cattle may be asymptomatic [42]. The positive blood samples in this study were from female animals, and there was no mention by the animal raisers during sample collection whether those animals had a history of any reproductive problems. Coxiellosis can cause reproductive problems, such as metritis [27], abortion, delivery of premature offspring, stillbirth, and weak offspring (or APSW complex, as termed by Agerholm [56]) in animals. On another note, subclinically infected animals identified in this study present a greater risk to the people working with them, because they can shed C. burnetii through their feces, vaginal fluids, milk, and parturition byproducts [9,57-60] without being identified as infected, due to absence of clinical signs. Moreover, six of those C. burnetii-positive animals are being raised for milk production, hence posing a health risk if the milk from those animals is consumed by humans without being pasteurized.

Coxiella burnetii was also found to be present in R. (B.) microplus ticks collected in this study. This result supports the previous report of Muramatsu et al. [61], wherein C. burnetii was also detected in two engorged R. (B.) microplus female ticks collected in Thailand through RFLP-nested PCR that also targeted the com1 gene. In contrast, another study in Thailand reported the non-detection of the pathogen in that tick after conventional PCR targeting the 16s $r R N A$ gene [21]. To date, there is still 
no report proving the role of $R$. (B.) microplus in transmitting C. burnetii in cattle. However, there is a possibility that this tick can harbor the pathogen, since a related Coxiella-endosymbiont has been found in different developmental stages and organs of the tick [62]. None of the animals from which the $C$. burnetii positive ticks were collected showed a positive result in the blood samples, which may be due to the absence or very low bacteremia at that time.

Serological evidence for rickettsiosis and $Q$ fever in humans has already been reported in the Philippines [31,32]. In the study of Camer et al., [31] antibodies against Rickettsia had been detected in febrile patients in two hospitals in the country. However, the authors did not detect antibodies against C. burnetii. On the other hand, a more recently published study by Cardona [32] demonstrated the presence of antibodies against $C$. burnetii in humans from two localities. Evidence of $Q$ fever in humans has also been reported in neighbouring Asian countries, such as Thailand [63] and Malaysia [64]. In Thailand, seropositive subjects included people working with ruminants, which led to the conclusion that exposure to those animals presents the risk of acquiring infection [63]. The findings in this study suggest that humans working closely with C. burnetii-positive animals should also be tested.

In summary, nested PCR showed that Rickettsia is absent in all blood and tick samples tested, whereas C. burnetii was found in cattle and water buffalo from two provinces and ticks in one province. To our knowledge, this study provides the first molecular evidence that $C$. burnetii is present in animal and tick populations in the Philippines. This result necessitates more thorough studies on prevalence, geographical distribution, transmission dynamics (including in other animals), and risk assessment in those two provinces, as well as in other regions of the Philippines. Serological studies should be done involving the people working closely with cattle, water buffalo, and other ruminants, to further assess exposure and risk of spreading. Molecular assays targeting other genes of Rickettsia and C. burnetti should be performed to improve detection sensitivity and further characterize positive samples. Lastly, a "One Health" approach involving medical and environmental professionals should be applied to control this threat to public health.

Supplementary Materials: The following are available online at http:/www.mdpi.com/2414-6366/5/2/54/s1. Table S1: Primers used for the amplification of control genes actin and $m t$-rrs in blood and tick samples, respectively, and detection of Rickettsia and Coxiella burnetii; Table S2: PCR conditions for the amplification of target fragments of control genes actin and mt-rrs in blood and tick samples, respectively, and the gltA gene of Rickettsia and com 1 gene of C. burnetii.

Author Contributions: Conceptualization, R.L.G., M.R.T., B.P.D., M.A., and T.T.; methodology, R.L.G., M.R.T., M.A., and T.T.; investigation, R.L.G., B.V.A.-S., D.M.M.C., L.M.O.d.C., C.M.A.S., D.K.B.C., K.A.C.S., F.H.G., J.A.B., J.L.V., L.C.B., C.R.A., and E.R.M.; formal analysis, R.L.G., M.R.T., B.P.D., M.A., and T.T.; writing-original draft preparation, B.V.A.-S., D.M.M.C., L.M.O.d.C., C.M.A.S., D.K.B.C., K.A.C.S., F.H.G., J.A.B., J.L.V., and L.C.B.; writing-review and editing, R.L.G., M.R.T., B.P.D., M.A., and T.T.; supervision, R.L.G., M.R.T., B.P.D., C.R.A., E.R.M., and T.T.; project administration, R.L.G., M.R.T., and T.T.; funding acquisition, R.L.G. and T.T. All authors have read and agreed to the published version of the manuscript.

Funding: This research was funded by the University of the Philippines Balik PhD (foreign-trained PhD) grant, as well as the Japan Society for the Promotion of Science, grant number 15H05264.

Acknowledgments: The authors are grateful to the staff of the offices of provincial veterinarians, municipal agriculturists, and the National Dairy Authority Southern Luzon for their assistance during sample collection, as well as to animal owners who allowed us to take samples from their animals. The authors are also thankful to the Takeda Science Foundation and the Ohshita Foundation.

Conflicts of Interest: The authors declare no conflict of interest.

\section{References}

1. Bondoc, O.L. Genetic diversity and relationship of domestic buffalo and cattle breeds and crossbreeds (subfamily Bovinae) in the Philippines based on the cytochrome c oxidase I(COI) gene sequence. Philipp. Agric. Sci. 2013, 96, 93-102.

2. Philippine Statistics Authority. Cattle Situation Report October to December 2019; Philippine Statistics Authority: Quezon City, Philippines, 2020. Available online: https://psa.gov.ph/livestock-poultry-iprs/cattle/inventory (accessed on 26 February 2020). 
3. Philippine Statistics Authority. Carabao Situation Report October to December 2019; Philippine Statistics Authority: Quezon City, Philippines, 2020. Available online: https://psa.gov.ph/livestock-poultry-iprs/ carabao/inventory (accessed on 26 February 2020).

4. Fournier, P.E.; Raoult, D. Current knowledge on the phylogeny and taxonomy of Rickettsia spp. Rickettsiology and Rickettsial Diseases—Fifth International Conference: Annals of the New York Academic. Sciences 2009, 1166, 1-11. [CrossRef]

5. Angelakis, E.; Raoult, D. Q fever. Vet. Microbiol. 2010, 140, 297-309. [CrossRef] [PubMed]

6. Azad, A.F.; Beard, C.B. Rickettsial pathogens and their arthropod vectors. Emerg. Infect. Dis. 1998, 4, $179-186$. [CrossRef]

7. Eremeeva, M.E.; Dasch, G.A. Challenges posed by tick-borne rickettsiae: Eco-epidemiology and public health implications. Front. Public Health 2015, 3, 1-17. [CrossRef]

8. Guatteo, R.; Seegers, H.; Taurel, A.F.; Joly, A.; Beaudeau, F. Prevalence of Coxiella burnetii infection in domestic ruminants: A critical review. Vet. Microbiol. 2011, 149, 1-16. [CrossRef]

9. OiE World Organisation for Animal Health 2012. Available online: https://www.oie.int/standard-setting/ terrestrial-manual/access-online/ (accessed on 9 April 2017).

10. Mcquiston, J.H.; Childs, J.E. Q Fever in Humans and Animals in the United States. Vector Borne Zoonotic Dis. 2002, 2, 179-191. [CrossRef]

11. Jilintai, N.S.; Seino, N.; Matsumoto, K.; Hayakawa, D.; Suzuki, M.; Hata, H.; Kondo, S.; Yokoyama, N.; Inokuma, H. Serological and molecular survey of Rickettsial infection in cattle and sika deer in a pastureland in Hidaka District, Hokkaido, Japan. Jpn. J. Infect. Dis. 2008, 61, 315-317.

12. Magouras, I.; Hunninghaus, J.; Scherrer, S.; Wittenbrink, M.M.; Hamburger, A.; Stärk, K.D.C.; Schüpbach-Regula, G. Coxiella burnetii Infections in Small Ruminants and Humans in Switzerland. Transbound. Emerg. Dis. 2015, 64, 204-212. [CrossRef]

13. Paul, S.; Agger, J.F.; Agerholm, J.S.; Markussen, B. Prevalence and risk factors of Coxiella burnetii seropositivity in Danish beef and dairy cattle at slaughter adjusted for test uncertainty. Prev. Vet. Med. 2014, 113, 504-511. [CrossRef]

14. Lyoo, K.S.; Kim, D.; Jang, H.G.; Lee, S.J.; Park, M.Y.; Hahn, T.W. Prevalence of Antibodies Against Coxiella burnetii in Korean Native Cattle, Dairy Cattle, and Dogs in South Korea. Vector-Borne Zoonotic Dis. 2017, 17, 213-216. [CrossRef] [PubMed]

15. Eisawi, N.M.; Hassan, D.A.; Hussien, M.O.; Musa, A.B.; El Hussein, A.R.M. Seroprevalence of spotted fever group (SFG) rickettsiae infection in domestic ruminants in Khartoum State, Sudan. Vet. Med. Sci. 2017, 3 , 91-98. [CrossRef] [PubMed]

16. Astobiza, I.; Ruiz-Fons, F.; Piñero, A.; Barandika, J.F.; Hurtado, A.L.; García-Pérez, A.L. Estimation of Coxiella burnetii prevalence in dairy cattle in intensive systems by serological and molecular analyses of bulk-tank milk samples. J. Dairy Sci. 2012, 95, 1632-1638. [CrossRef] [PubMed]

17. Gyuranecz, M.; Dénés, B.; Hornok, S.; Kovács, P.; Horváth, G.; Jurkovich, V.; Varga, T.; Hajtós, I.; Szabó, R.; Magyar, T.; et al. Prevalence of Coxiella burnetii in Hungary: Screening of dairy cows, sheep, commercial milk samples, and ticks. Vector-Borne Zoonotic Dis. 2012, 12, 1-4. [CrossRef] [PubMed]

18. Sulyok, K.M.; Kreizinger, Z.; Hornstra, H.M.; Pearson, T.; Szigeti, A.; Dán, A.; Balla, E.; Keirn, P.S.; Gyuranecz, M. Genotyping of Coxiella burnetii from domestic ruminants and human in Hungary: Indication of various genotypes. BMC Vet. Res. 2014, 10, 107. [CrossRef]

19. Pesquera, C.; Portillo, A.; Palomar, A.M.; Oteo, J.A. Investigation of tick-borne bacteria (Rickettsia spp., Anaplasma spp., Ehrlichia spp. and Borrelia spp.) in ticks collected from Andaean tapirs, cattle and vegetation from a protected area in Ecuador. Parasites Vectors 2015, 8, 46. [CrossRef]

20. Cumbassa, A.; Barahona, M.J.; Cunha, M.V.; Azorin, B.; Fonseca, C.; Rosalino, L.M.; Tilburg, J.; Hagen, F.; Santos, A.S.; Botelho, A. Coxiella burnetti DNA detected in domestic ruminants and wildlife from Portugal. Vet. Microbiol. 2015, 180, 136-141. [CrossRef]

21. Sumrandee, C.; Baimai, V.; Trinachartvanit, W.; Ahantarig, A. Molecular detection of Rickettsia, Anaplasma, Coxiella and Francisella bacteria in ticks collected from Artiodactyla in Thailand. Ticks Tick Borne Dis. 2016, 7 , 678-689. [CrossRef]

22. Karim, S.; Budachetri, K.; Mukherjee, N.; Williams, J.; Kausar, A.; Hassan, M.J.; Adamson, S.; Dowd, S.E.; Apanskevich, D.; Arijo, A.; et al. A study of ticks and tick-borne livestock pathogens in Pakistan. PLoS Negl. Trop. Dis. 2017, 11, e0005681. [CrossRef] 
23. Liu, D. Chapter 111-Rickettsia. In Molecular Medical Microbiology, 2nd ed.; Tang, Y., Liu, D., Schwartzman, J., Sussman, M., Poxton, I., Eds.; Elsevier Ltd.: Alpharetta, GA, USA, 2015; pp. 2043-2045.

24. Bechah, Y.; Capo, C.; Mege, J.L.; Raoult, D. Rickettsial diseases: From Rickettsia-arthropod relationships to pathophysiology and animal models. Future Microbiol. 2008, 3, 223-236. [CrossRef]

25. Aung, A.K.; Spelman, D.W.; Murray, R.J.; Graves, S. Rickettsial Infections in Southeast Asia: Implications for Local Populace and Febrile Returned Travelers. Am. J. Trop. Med. Hyg. 2014, 91, 451-460. [CrossRef] [PubMed]

26. Maurin, M.; Raoult, D. Q fever. Clin. Microbiol. Rev. 1999, 12, 518-553. [CrossRef] [PubMed]

27. Arricau-Bouvery, N.; Rodolakis, A. Is Q fever an emerging or re-emerging zoonosis? Vet. Res. 2005, 36, 327-349. [CrossRef] [PubMed]

28. Parisi, A.; Fraccalvieri, R.; Cafiero, M.; Miccolupo, A.; Padalino, I.; Montagna, C.; Capuano, F.; Sottili, R. Detection of Coxiella burnetii-related abortion in Italian domestic ruminants using single-tube nested PCR. Vet. Microbiol. 2006, 118, 101-106. [CrossRef] [PubMed]

29. Gürtler, L.; Bauerfeind, U.; Blümel, J.; Burger, R.; Drosten, C.; Gröner, A.; Heiden, M.; Hildebrandt, M.; Jansen, B.; Offergeld, R.; et al. Coxiella burnetti-Pathogenic Agent of Q (Query) Fever. Transfus. Med. Hemother. 2014, 41, 60-72. [CrossRef]

30. Ybañez, A.P.; Mingala, C.N.; Ybañez, R.H.D. Historical review and insights on the livestock tick-borne disease research of a developing country: The Philippine scenario. Parasitol. Int. 2018, 67, 262-266. [CrossRef]

31. Camer, G.A.; Alejandria, M.; Amor, M.; Satoh, H.; Muramatsu, Y.; Ueno, H.; Morita, C. Detection of Antibodies against Spotted Fever Group Rickettsia (SFGR), Typhus Group Rickettsia (TGR), and Coxiella burnetii in Human Febrile Patients in the Philippines. Jpn. J. Infect. Dis. 2003, 56, 26-28.

32. Cardona, F. Serological Detection of Q-Fever in the Sera of Humans and Ruminants in Selected Areas in the Philippines. IAMURE Int. J. Ecol. Conserv. 2016, 18, 108-117. [CrossRef]

33. Galay, R.L.; Manalo, A.A.L.; Dolores, S.L.D.; Aguilar, I.P.M.; Sandalo, K.A.C.; Cruz, K.B.; Divina, B.P.; Andoh, M.; Masatani, T.; Tanaka, T. Molecular detection of tick-borne pathogens in canine population and Rhipicephalus sanguineus (sensu lato) ticks from southern Metro Manila and Laguna, Philippines. Parasites Vectors 2018, 11, 1-8. [CrossRef]

34. Barker, S.C.; Walker, A.R. Ticks of Australia. The species that infest domestic animals and humans. Zootaxa 2014, 3816, 1-144. [CrossRef]

35. Belotindos, L.P.; Lazaro, J.V.; Villanueva, M.A.; Mingala, C.N. Molecular detection and characterization of Theileria species in the Philippines. Acta Parasitol. 2014, 59, 448-453. [CrossRef] [PubMed]

36. Ushijima, Y.; Oliver, J.J.; Keirans, J.; Tsurumi, M.; Kawabata, H.; Watanabe, H.; Fukunaga, M. Mitochondrial sequence variation in Carlos capensis (Neumann), a parasite of seabirds, collected on Torishima Island in Japan. J. Parasitol. 2003, 89, 196-198. [CrossRef]

37. Mediannikov, O.Y.; Sidelnikov, Y.; Ivanov, L.; Mokretsova, E.; Fournier, P.E.; Tarasevich, I.; Raoult, D. Acute tick-borne rickettsiosis caused by Rickettsia heilongjiangensis in Russian Far East. Emerg. Infect. Dis. 2004, 10, 810-817. [CrossRef] [PubMed]

38. Zhang, G.Q.; Nguyen, S.A.V.; To, H.; Ogawa, M.; Hotta, A.; Yamaguchi, T.; Kim, H.; Fukushi, H.; Hirai, K. Clinical Evaluation of a new PCR assay for detection of Coxiella burnetii in human serum samples. J. Clin. Microbiol. 1998, 36, 77-80. [CrossRef] [PubMed]

39. Camer, G.A.; Masangkay, J.; Satoh, H.; Okabayashi, T.; Norizuki, S.; Motoi, Y.; Ueno, H.; Morita, C. Prevalence of spotted fever rickettsial antibodies in dogs and rodents in the Philippines. Jpn. J. Infect. Dis. 2000, 53, 162-163. [PubMed]

40. Maina, A.N.; Jiang, J.; Omulo, S.A.; Cutler, S.J.; Ade, F.; Ogola, E.; Feikin, D.; Njenga, M.K.; Cleaveland, S.; Mpoke, S.; et al. High Prevalence of Rickettsia africae Variants in Amblyomma variegatum Ticks from Domestic Mammals in Rural Western Kenya: Implications for Human Health. Vector Borne Zoonotic Dis. 2014, 14, 693-702. [CrossRef] [PubMed]

41. Monje, L.D.; Linares, M.C.; Beldomenico, P.M. Prevalence and infection intensity of Rickettsia massiliae in Rhipicephalus sanguineus sensu lato ticks from Mendoza, Argentina. Microbes Infect. 2016, 18, 701-705. [CrossRef] [PubMed] 
42. Eraso-Cadena, M.P.; Molina-Guzmán, L.P.; Cardona, X.; Cardona-Arias, J.A.; Ríos-Osorio, L.A.; Gutierrez-Builes, L.A. Serological evidence of exposure to some zoonotic microorganisms in cattle and humans with occupational exposure to livestock in Antioquia, Colombia. Cad. Saude. Publica 2018, 34, 1-16. [CrossRef] [PubMed]

43. Edwards, K.T.; Goddard, J.; Jones, T.L.; Paddock, C.D.; Varela-Stokes, A.S. Cattle and the Natural History of Rickettsia parkeri in Mississippi. Vector Borne Zoonotic Dis. 2011, 11, 485-491. [CrossRef]

44. Hornok, S.; Sugár, L.; Fernández de Mera, I.G.; de la Fuente, J.; Horváth, G.; Kovács, T.; Micsutka, A.; Gönczi, E.; Flaisz, B.; Takács, N.; et al. Tick- and fly-borne bacteria in ungulates: The prevalence of Anaplasma phagocytophilum, haemoplasmas and rickettsiae in water buffalo and deer species in Central Europe, Hungary. BMC Vet. Res. 2018, 14, 98. [CrossRef]

45. Abanda, B.; Paguem, A.; Abdoulmoumini, M.; Kingsley, M.T.; Renz, A.; Eisenbarth, A. Molecular identification and prevalence of tick-borne pathogens in zebu and taurine cattle in North Cameroon. Parasites Vectors 2019, 12, 1-13. [CrossRef] [PubMed]

46. Paris, D.H.; Dumler, J.S. State of the art of diagnosis of rickettsial diseases: The use of blood specimens for diagnosis of scrub typhus, spotted fever group rickettsiosis, and murine typhus. Curr. Opin. Infect. Dis. 2016, 29, 433-439. [CrossRef]

47. Roux, V.; Rydkina, E.; Eremeeva, M.; Raoult, D. Citrate synthase gene comparison, a new tool for phylogenetic analysis, and its application for the rickettsiae. Int. J. Syst. Biol. 1997, 47, 252-261. [CrossRef]

48. Stenos, J.; Graves, S.R.; Unsworth, N.B. A highly sensitive and specific real-time PCR assay for the detection of spotted fever and typhus group rickettsiae. Am. J. Trop. Med. Hyg. 2005, 73, 1083-1085. [CrossRef]

49. Santibañez, S.; Portillo, A.; Santibañez, P.; Polmar, A.M.; Oteo, J.A. Usefulness of rickettsial PCR assays for the molecular diagnoses of human rickettsioses. Enferm. Infecc. Microbiol. Clín. 2013, 31, 283-288. [CrossRef]

50. Fernández de Mera, I.G.; Blanda, V.; Torina, A.; Dabaja, M.F.; Romeh, A.E.; Cabezas-Cruz, A.; De la Fuente, J. Identification and molecular characterization of spotted fever group rickettsiae in ticks collected from farm ruminants in Lebanon. Ticks Tick Borne Dis. 2018, 9, 104-108. [CrossRef] [PubMed]

51. Cicculli, V.; Capai, L.; Quilichini, Y.; Masse, S.; Fernández-Alvarez, A.; Minodier, L.; Bompard, P.; Charrel, R.; Falchi, A. Molecular investigation of tick-borne pathogens in ixodid ticks infesting domestic animals (cattle and sheep) and small rodents (black rats) of Corsica, France. Ticks Tick Borne Dis. 2019, 10, 606-613. [CrossRef]

52. Cicculli, V.; Oscar, M.; Casabianca, F.; Villechenaud, N.; Charrel, R.; de Lamballerie, X.; Falchi, A. Molecular Detection of Spotted-Fever Group Rickettsiae in Ticks Collected from Domestic and Wild Animals in Corsica, France. Pathogens 2019, 8, 138. [CrossRef]

53. Guo, H.; Moumouni, P.A.A.; Thekisoe, O.; Gao, Y.; Liu, M.; Li, J.; Galon, E.M.; Efstratiou, A.; Wang, G.; Jirapattharasate, C.; et al. Genetic characterization of tick-borne pathogens in ticks infesting cattle and sheep from three South African provinces. Ticks Tick Borne Dis. 2019, 10, 875-882. [CrossRef]

54. Phan, J.N.; Lu, C.R.; Bender, W.G.; Smoak, R.M., 3rd; Zhong, J. Molecular detection and identification of Rickettsia species in Ixodes pacificus in California. Vecto. Borne Zoonotic Dis. 2011, 11, 957-961. [CrossRef]

55. Kurtti, T.J.; Felsheim, R.F.; Burkhardt, N.Y.; Oliver, J.D.; Heu, C.C.; Munderloh, U.G. Rickettsia buchneri sp. nov., a rickettsial endosymbiont of the blacklegged tick Ixodes scapularis. Int. J. Syst. Evol. Microbiol. 2015, 65, 965-970. [CrossRef] [PubMed]

56. Agerholm, J.S. Coxiella burnetii associated reproductive disorders in domestic animals-A critical review. Acta Vet. Scand. 2013, 55, 1-11. [CrossRef] [PubMed]

57. Lorenz, H.; Jāger, C.; Willems, H.; Baljer, G. PCR Detection of Coxiella burnetii from Different Clinical Specimens, Especially Bovine Milk, on the Basis of DNA Preparation with a Silica Matrix. Appl. Environ. Microbiol. 1998, 64, 4234-4237. [CrossRef] [PubMed]

58. Berri, M.; Souriau, A.; Crosby, M.; Crochet, D.; Lechopier, P.; Rodolakis, A. Relationships between the shedding of Coxiella burnetii, clinicial signs and serological responses of 34 sheep. Vet. Rec. 2001, 148, 502-505. [CrossRef]

59. Arricau-Bouvery, N.; Souriau, A.; Lechopier, P.; Rodolakis, A. Experimental Coxiella burnetii infection in pregnant goats: Excretion routes. Vet. Res. 2003, 34, 423-433. [CrossRef]

60. Guatteo, R.; Beaudeau, F.; Berri, M.; Rodolakis, A.; Joly, A.; Seegers, H. Shedding routes of Coxiella burnetii in dairy cows: Implications for detection and control. Vet. Res. 2006, 37, 827-833. [CrossRef] 
61. Muramatsu, Y.; Noriyo, U.; Thongchai, C.; Kramomtong, I.; Kriengsak, P.; Tamura, Y. Seroepidemiologic survey in Thailand of Coxiella burnetii infection in cattle and chickens and presence in ticks attached to cattle. Southeast Asian J. Trop. Med. Public Health 2014, 45, 1167-1172.

62. Guizzo, M.G.; Parizi, L.F.; Nunes, R.D.; Schama, R.; Albano, R.M.; Tirloni, L.; Oldiges, D.P.; Vieira, R.P.; Oliveira, W.H.C.; Leite, M.S.; et al. A Coxiella mutualist symbiont is essential to the development of Rhipicephalus microplus. Sci. Rep. 2017, 7, 1-10. [CrossRef]

63. Doung-ngern, P.; Chuxnum, T.; Pangjai, D.; Opaschaitat, P.; Kittiwan, N.; Rodtian, P.; Buameetoop, N.; Kersh, G.J.; Padungtod, P. Seroprevalence of Coxiella burnetii Antibodies among Ruminants and Occupationally Exposed People in Thailand, 2012-2013. Am. J. Trop. Med. Hyg. 2017, 96, 786-790. [CrossRef]

64. Khor, C.S.; Mohd-Rahim, N.F.; Hassan, H.; Chandren, J.R.; Nore, S.; Johari, J.; Loong, S.; Abd-Jamil, J.; Khoo, J.; Lee, H.; et al. Seroprevalence of Q Fever Among the Indigenous People (Orang Asli) of Peninsular Malaysia. Vector Borne Zoonotic Dis. 2018, 18, 131-137. [CrossRef]

(C) 2020 by the authors. Licensee MDPI, Basel, Switzerland. This article is an open access article distributed under the terms and conditions of the Creative Commons Attribution (CC BY) license (http://creativecommons.org/licenses/by/4.0/). 